\title{
Layer-bounding surfaces in stalagmites as keys to better paleoclimatological histories and chronologies
}

\author{
L. Bruce Railsback ${ }^{1 *}$, Pete D. Akers ${ }^{2}$, Lixin Wang ${ }^{2}$, Genevieve A. Holdridge ${ }^{2}$, \\ and Ny Riavo Voarintsoa ${ }^{1}$ \\ ${ }^{1}$ Department of Geology, University of Georgia, Athens, Georgia 30602-2501 USA \\ 2 Department of Geography, University of Georgia, Athens, Georgia 30602-2502 USA
}

Abstract: Petrographic recognition of layer-bounding surfaces in stalagmites offers an important tool in constructing paleoclimate records. Previous petrographic efforts have examined thickness of layers (a possible proxy for annual rainfall) and alternation of layers in couplets (a possible indicator of seasonality). Layer-bounding surfaces, in contrast, delimit series of layers and represent periods of non-deposition, either because of exceptionally wet or exceptionally dry conditions.

Two types of layer-bounding surfaces can be recognized according to explicitly defined petrographic criteria. Type E layer-bounding surfaces are surfaces at which layers have been truncated or eroded at the crest of a stalagmite. Keys to their recognition include irregular termination of layers otherwise present on the stalagmite's flank, dissolutional cavities, and coatings of non-carbonate detrital materials. Type $\mathrm{E}$ surfaces are interpreted to represent wet periods during which drip water became so undersaturated as to dissolve pre-existing stalagmite layers, and thus they necessarily represent hiatuses in the stalagmite record.

Type $L$ layer-bounding surfaces are surfaces below which layers become thinner upward and/or layers have lesser lateral extent upward, so that the stalagmite's layer-specific width decreases. They are thus surfaces of lessened deposition and are interpreted to represent drier conditions in which drip rate slowed so much that little deposition occurred. A Type L surface may, but does not necessarily, represent a hiatus in deposition. However, radiometric age data show that Type $L$ surfaces commonly represent significant hiatuses.

These surfaces are significant to paleoclimate research both for their implications regarding climate change (exceptionally wet or dry conditions) and in construction of chronologies in which other data, such as stable isotope ratios, are placed. With regard to climate change, recognition of these surfaces provides paleoclimatological information that can complement or even substitute for geochemical proxies. With regard to chronologies, recognition of layerbounding surfaces allows correct placement of hiatuses in chronologies and thus correct placement of geochemical data in time series. Attention to changing thickness of annual layers and thus to accumulation rate can also refine a chronology. A chronology constructed with attention to layer-bounding surfaces and to changing layer thickness is much more accurate than a chronology in which hiatuses are not recognized at such surfaces.

Keywords: $\quad$ stalagmites; paleoclimate; petrography; age models; chronologies

Received 21 February 2013; Revised 3 June 2013; Accepted 15 June 2013

Citation: Railsback L.B., Akers P.D., Wang L., Holdridge G.A. and Voarintsoa N.R., 2013. Layerbounding surfaces in stalagmites as keys to better paleoclimatological histories and chronologies. International Journal of Speleology, 42 (3), 167-180. Tampa, FL (USA) ISSN 0392-6672 http://dx.doi.org/10.5038/1827-806X.42.3.1

\section{INTRODUCTION}

In the last twenty years, the application of stalagmites to the study of past climate has expanded explosively: a bibliographic survey indicates a fifteenfold increase in such papers from 1990 to 2010. By far the data most commonly collected and applied from stalagmites have been stable isotope ratios, and these are largely $\delta^{18} \mathrm{O}$ data. Combination of these data, which are now well understood (McDermott, 2004; Lachniet, 2009; Fairchild \& Baker, 2012), with U-Th dating via inductively-coupled plasma mass spectrometry (Shen et al., 2002) and other methods (Drysdale et al., 2012) has allowed development of detailed and seemingly continuous records of climate change.

In the application of stalagmites to paleoclimatology, the petrography of stalagmites (Railsback et al., 1994; Turgeon \& Lundberg, 2001; Frisia et al., 2002) has not been used widely. One occasional application of petrography has been the counting of apparently annual layers and measurement of their thickness (e.g., Baker et al., 1993; Brook et al., 1999; Polyak \& 
Asmerom, 2001). However, exact counting of layers is subject to interpretation (e.g., Railsback et al., 1994), and the complexities of the controls on layer thickness are only now becoming known (Tan et al., 2006; Mariethoz et al., 2012).

With the previously undeveloped state of stalagmite petrography in mind, this paper proposes that a more useful approach to understanding the history of a stalagmite's deposition is not the study of just the layers themselves but instead the study of layer-bounding surfaces (Fig. 1). A layer-bounding surface is a surface at which underlying layers are terminated. Such surfaces can be divided into two types that can be identified by objective criteria and that have very different origins. One kind, Type E, results from dissolutional erosion, whereas the other, Type L, results from lessened growth (Table 1). This focus on layer-bounding surfaces, rather than layers themselves, is akin to the wildly successful application of sequence stratigraphy to sedimentary strata, where rock layers themselves are less critical than layer-bounding erosional surfaces (unconformities recognized as sequence boundaries) and condensation zones representing slower deposition (and commonly recognized as maximum-flooding surfaces) (Vail et al., 1977).

The recognition of layer-bounding surfaces is significant to paleoclimate studies for two reasons. First, both dissolutional erosion (suggested by Type E surfaces) and lesser deposition (suggested by Type L surfaces) imply significant changes toward wetter and drier climate regimes, respectively. Recognition of these surfaces thus provides evidence of climate change. Secondly, Type E surfaces necessarily represent hiatuses, and Type L surfaces likely represent hiatuses. Recognition of these surfaces thus changes the construction of chronologies and suggests that the "seemingly continuous records of climate change" mentioned above may not be as continuous as commonly thought.

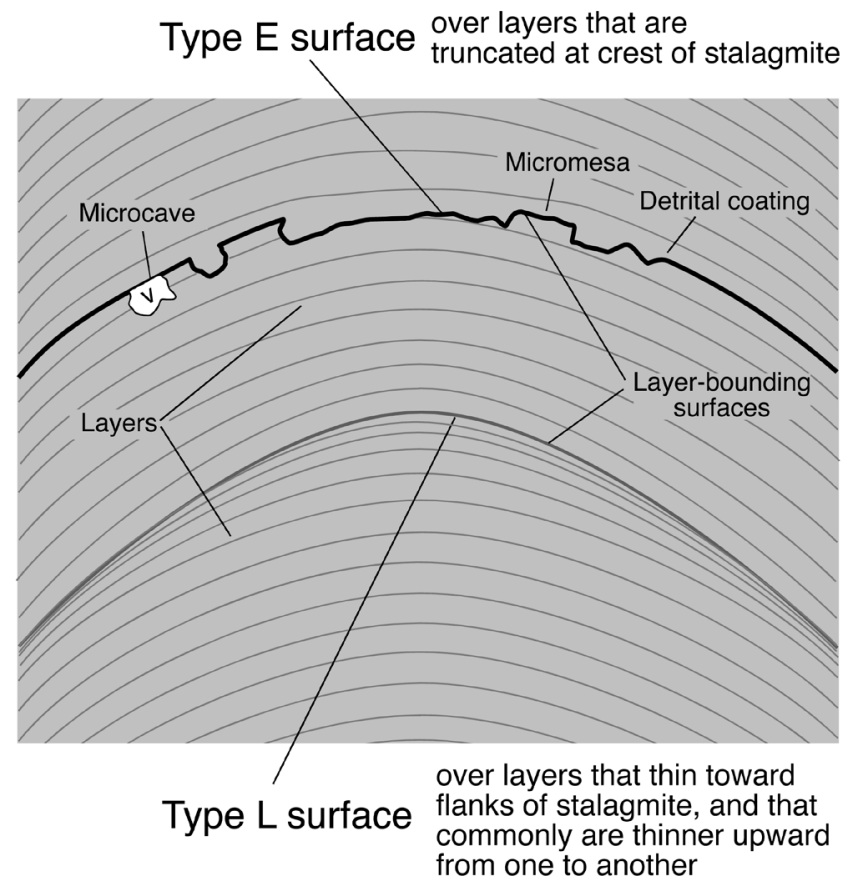

Fig. 1. Schematic cross-section of a stalagmite showing idealized Type $\mathrm{E}$ and Type L layer-bounding surfaces.
Table 1. Characteristics of, and inferences from, layer-bounding surfaces in stalagmites.

\begin{tabular}{|c|c|c|}
\hline & Type E (for "Erosional") & Type L (for "Lessened") \\
\hline Defining morphology & $\begin{array}{l}\text { Layer or layers truncated, } \\
\text { commonly near crest of } \\
\text { stalagmite }\end{array}$ & $\begin{array}{l}\text { Layer, or more commonly } \\
\text { layers, thin toward flanks of } \\
\text { stalagmite }\end{array}$ \\
\hline $\begin{array}{l}\text { Key/diagnostic } \\
\text { features }\end{array}$ & $\begin{array}{l}\text { Micro-topographic features: } \\
\text { mesas, escarpments, caves }\end{array}$ & $\begin{array}{c}\text { Upwards-thinning, laterally less } \\
\text { extensive layers }\end{array}$ \\
\hline $\begin{array}{l}\text { Relationship to width } \\
\text { of stalagmite }\end{array}$ & Typically none & Stalagmite may narrow \\
\hline $\begin{array}{l}\text { Characteristics of } \\
\text { sequence of layers } \\
\text { below surface }\end{array}$ & $\begin{array}{l}\text { Commonly no distinctive } \\
\text { sequence; layers below may } \\
\text { thicken upwards or contain } \\
\text { detrital grains }\end{array}$ & $\begin{array}{l}\text { Commonly thinning upwards to } \\
\text { surface, so that interval below } \\
\text { surface is a zone of transition }\end{array}$ \\
\hline Mineralogical trends & $\begin{array}{l}\text { Either aragonite or calcite } \\
\text { below surface; commonly } \\
\text { calcite above }\end{array}$ & $\begin{array}{l}\text { Aragonite commonly below } \\
\text { surface, especially in warmer } \\
\text { settings }\end{array}$ \\
\hline $\begin{array}{l}\text { Non-carbonate detrital } \\
\text { material }\end{array}$ & $\begin{array}{l}\text { Commonly abundant; can } \\
\text { contain coarse (silt to sand) } \\
\text { grains }\end{array}$ & $\begin{array}{l}\text { Commonly scarce; may be } \\
\text { a thin horizon of very fine } \\
\text { material (dust) }\end{array}$ \\
\hline $\begin{array}{l}\text { Stable isotope } \\
\text { relationships }\end{array}$ & $\begin{array}{c}\text { Commonly none; } \\
\text { discontinuity across surface } \\
\text { possible }\end{array}$ & $\begin{array}{l}\text { Typically increase } \delta^{13} \mathrm{C} \text {, and } \\
\text { commonly increase in } \delta^{18} \mathrm{O} \text {, of } \\
\text { spelean } \mathrm{CaCO}_{3} \text { below surface }\end{array}$ \\
\hline Inferred processes & $\begin{array}{c}\text { Dissolutional erosion by } \\
\text { abundant undersaturated } \\
\text { dripwater }\end{array}$ & $\begin{array}{l}\text { Lessened deposition by } \\
\text { diminished dripwater }\end{array}$ \\
\hline $\begin{array}{l}\text { Paleolimatological } \\
\text { implications }\end{array}$ & $\begin{array}{l}\text { Increased atmospheric } \\
\text { precipitation }\end{array}$ & $\begin{array}{l}\text { Decreased atmospheric } \\
\text { precipitation }\end{array}$ \\
\hline $\begin{array}{l}\text { Chronological } \\
\text { implications }\end{array}$ & $\begin{array}{l}\text { Non-representation (hiatus) } \\
\text { of time of dissolution and } \\
\text { of time in which dissolved } \\
\text { layers were deposited }\end{array}$ & $\begin{array}{l}\text { Likely non-representation } \\
\text { (hiatus) of time after last } \\
\text { diminished layers }\end{array}$ \\
\hline
\end{tabular}

\section{MATERIALS}

This paper presents images of fourteen stalagmites from five continents and from the island of Madagascar (Table 2). The stalagmites are from locations with present average annual precipitation ranging from $\leq 400$ to $\geq 2400 \mathrm{~mm}$, and they range in age from $170 \mathrm{ka}$ (Stalagmite GG) to 14 years BP (Stalagmite DP1), where "BP” indicates time before 1950.

Table 2. Stalagmites illustrated in this paper.

\begin{tabular}{|c|c|c|c|c|}
\hline Stalagmite & Cave & Location & $\begin{array}{c}\text { Annual } \\
\text { atmospheric } \\
\text { precipitation } \\
(\mathrm{mm})\end{array}$ & $\begin{array}{l}\text { Relevant } \\
\text { literature }\end{array}$ \\
\hline ANJ94-5 & Anjohibe Cave & NW Madagascar & 1500 & $\begin{array}{l}\text { Work in } \\
\text { progress }\end{array}$ \\
\hline BC97-14 & Bone Cave & NW Botswana & 450 & $\begin{array}{l}\text { Work in } \\
\text { progress }\end{array}$ \\
\hline BRU11 & $\begin{array}{l}\text { Las Brujas } \\
\text { Cave }\end{array}$ & W Argentina & 400 & $\begin{array}{l}\text { Work in } \\
\text { progress }\end{array}$ \\
\hline BZBT1 & $\begin{array}{l}\text { Box Tunich } \\
\text { Cave }\end{array}$ & W Belize & 2360 & Akers (2011) \\
\hline $\mathrm{CH} 1$ & $\begin{array}{c}\text { Yangzhipo } \\
\text { Cave }\end{array}$ & SE China & 1140 & Xiao (2003) \\
\hline DP1 & Dante Cave & NE Namibia & 532 & $\begin{array}{l}\text { Sletten et al. } \\
\quad(2013)\end{array}$ \\
\hline EG1 & $\begin{array}{l}\text { La Gruta de } \\
\text { San Isidro, } \\
\text { Apazco }\end{array}$ & SW Mexico & 674 & $\begin{array}{l}\text { Work in } \\
\text { progress }\end{array}$ \\
\hline ESP03 & Cova da Arcoia & NW Spain & 2500 & $\begin{array}{c}\text { Railsback et al. } \\
\text { (2011) }\end{array}$ \\
\hline ESP04 & Cova da Arcoia & NW Spain & 2500 & $\begin{array}{l}\text { Work in } \\
\text { progress }\end{array}$ \\
\hline GG & $\begin{array}{c}\text { Carlsbad } \\
\text { Cavern }\end{array}$ & SW United States & 379 & $\begin{array}{c}\text { Brook et al. } \\
(2006)\end{array}$ \\
\hline MA3 & Anjohibe Cave & NW Madagascar & 1500 & $\begin{array}{l}\text { Work in } \\
\text { progress }\end{array}$ \\
\hline MC & Macal Chasm & W Belize & 1500 & $\begin{array}{c}\text { Webster et al. } \\
(2007)\end{array}$ \\
\hline WGI & $\begin{array}{l}\text { Wow Gdoom } \\
\text { Cave }\end{array}$ & NW Namibia & 300 & $\begin{array}{l}\text { Work in } \\
\text { progress }\end{array}$ \\
\hline Wudu & $\begin{array}{l}\text { Wanxiang } \\
\text { Cave }\end{array}$ & N China & 480 & Xiao (2003) \\
\hline
\end{tabular}


TYPE E SURFACES

\section{Petrography}

Type E layer-bounding surfaces are surfaces at which layers evident on the flanks of a stalagmite have been truncated or eroded at the stalagmite's crest (Fig. 1). The " $E$ " is thus a reminder of erosion. This erosion commonly generates micro-topographic features analogous to landscape features in regions of eroded sedimentary strata. For example, erosion of most, but not all, of the lateral extent of a layer can leave an isolated remnant analogous to a landscape's mesa (Figs. 2A and 2C). Truncation of layers generates stair-step-like surfaces analogous to erosional escarpments of landscapes (Figs. 2B, $2 \mathrm{D}, 2 \mathrm{E}$, and $3 \mathrm{~A})$, and localized removal of layers generates valley-like features (Fig. 3B). Dissolution below the surface of the stalagmite can leave holes analogous to the caves of a karst landscape (Fig. 4). The latter features commonly develop where clays have coated most of the surface of stalagmite, precluding dissolution where that coating is present, but where gaps in the coating allow penetration of
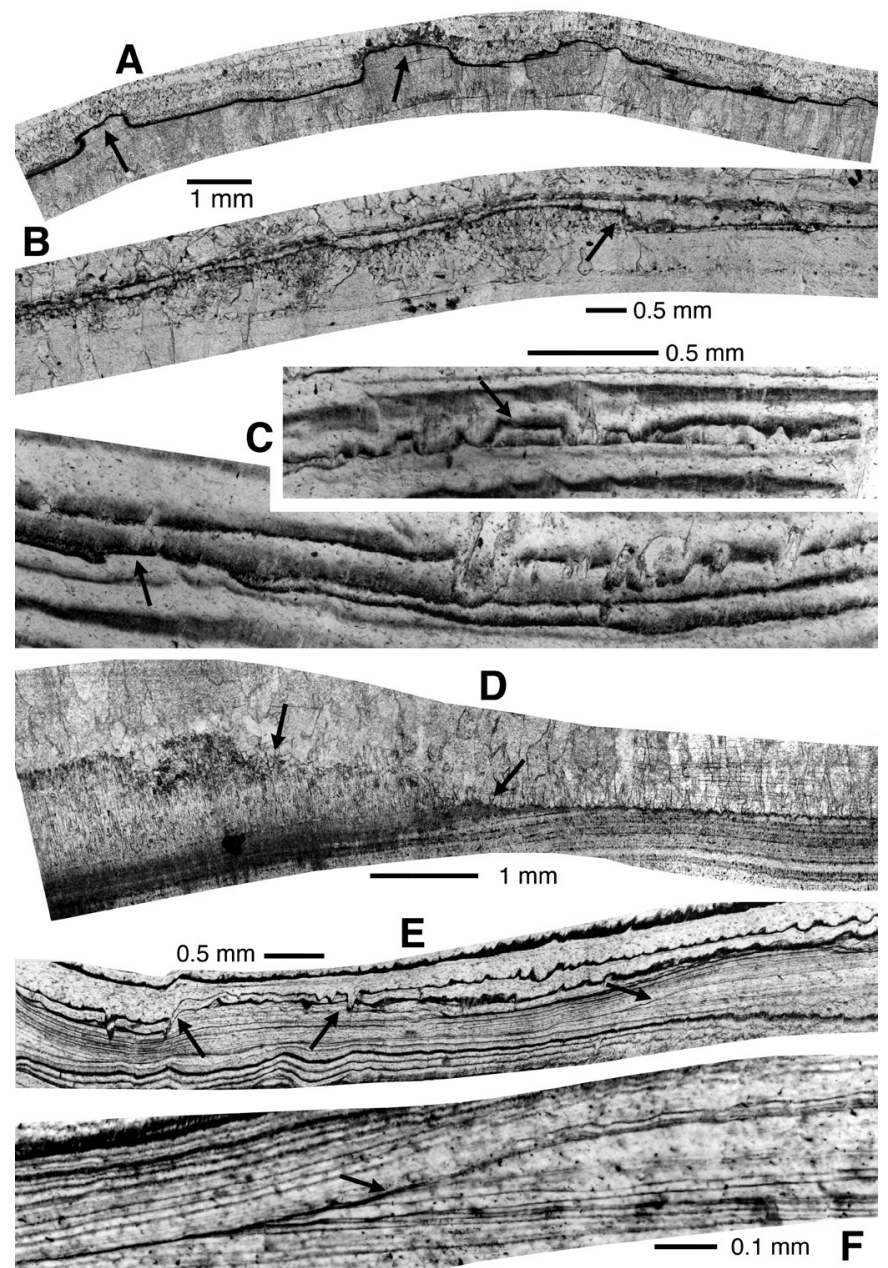

Fig. 2. Examples of Type $E$ layer-bounding surfaces. A. Mesa-like erosional remnants at a Type $E$ surface marked by opaque detrital material in Stalagmite ESP03 from northwestern Spain. B. Truncation of layer at an escarpment-like termination in Stalagmite BZBT1 from Belize. C. Two illustrations of mesa-like erosional remnants in Wudu Stalagmite from north-central China. D. Escarpment-like truncation surface in Stalagmite ESP03 from northwestern Spain. E. Escarpment-like truncation surface in Stalagmite ESP04 from northwestern Spain. F. Enlargement of area at rightmost arrow in $\mathrm{E}$ showing truncation. water that dissolves underlying $\mathrm{CaCO}_{3}$ to create cavities analogous to caves. At least two examples show the transition in one layer from cavity-ridden microkarst to complete removal of that layer at the crest of the stalagmite (Figs. 4A and 4B).

Other features are commonly associated with Type E surfaces. Type E surfaces commonly have coatings
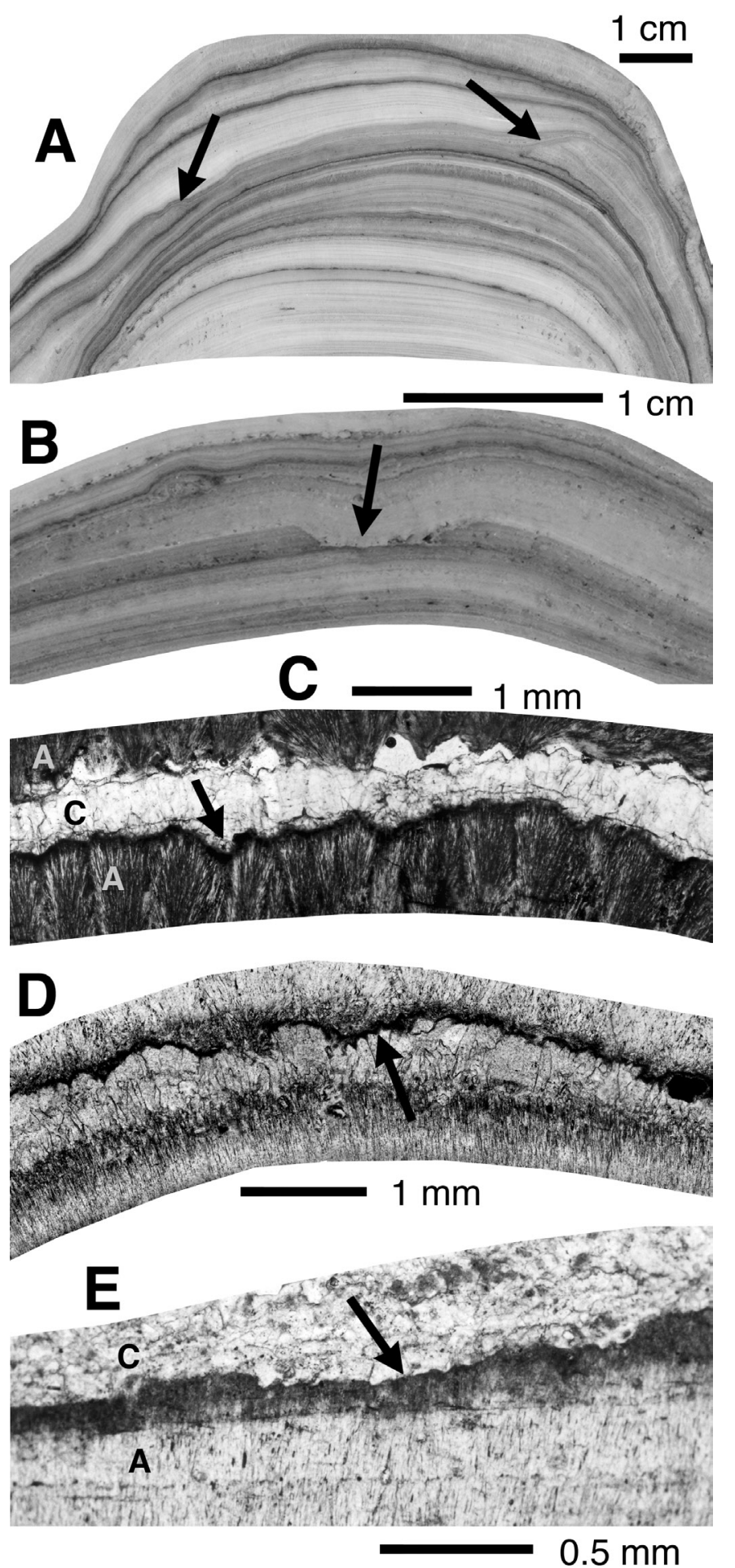

Fig. 3. Examples of Type $E$ layer-bounding surfaces. On images, " $A$ " indicates aragonite and " $C$ " indicates calcite. A. Matching escarpment-like surfaces below a Type E surface in Stalagmite WG1 from Namibia. B. Valley-like erosional feature in Stalagmite WG1 from Namibia. C. Irregular surface of erosion on aragonite in Stalagmite $\mathrm{CH} 1$ from southeastern China. Note similarity of this surface to that on the left side of Figure 4B. D. Irregular surface of erosion on calcite in Stalagmite ESP03 from northwestern Spain. E. Irregular surface of erosion on aragonite in Stalagmite BC97-14 from northwestern Botswana. 


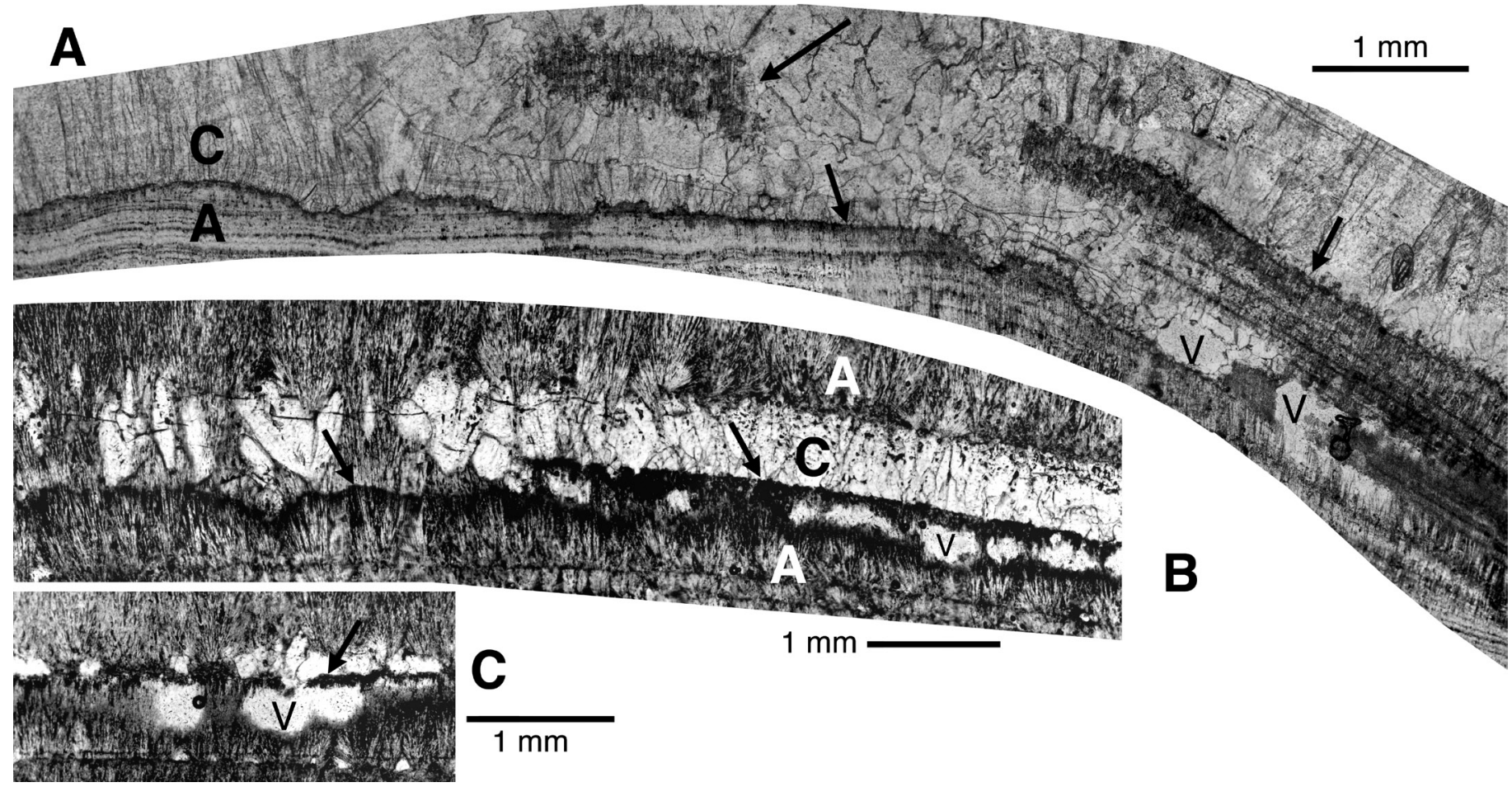

Fig. 4. Cave-like dissolutional cavities at Type E layer-bounding surfaces. On images, "A" indicates aragonite and "C" indicates calcite. A. Type E surface (two shorter arrows) with an escarpment in which cavities (V) have been opened by dissolution of aragonite. Longer arrow points to a remnant of the aragonite layer seen at right. Stalagmite ESP03 from northwestern Spain. B. Type E surface (arrows) with an escarpment in which cavities (V) have been opened by dissolution of aragonite in Stalagmite DP1 from northeastern Namibia. C. Cavities (V) opened by dissolution of aragonite in Stalagmite DP1 from northeastern Namibia. In both B and C, note dark coatings of detrital material, mostly clay, inhibiting dissolution of aragonite surface; cavities presumably develop where coating is penetrated by corrosive drip water.

of non-carbonate clay (or, more generally, "mud"), although aggregates of clay as large as silt and fine-grain sand can commonly be recognized within these coatings (Figs. 2A, 3C, 3D, 3E, 4B, and 4C). Larger detrital grains, as large as medium-grained sand and consisting of carbonates, phosphates, and silicates, are also sometimes found near Type $\mathrm{E}$ surfaces. One might infer that the fine-grained (clay-size) material could have been deposited either as wind-blown dust or in drip water, but the coarser detrital grains and aggregates are too large to have been carried by air in the interiors of caves and instead suggest deposition from gushing drip water.

The Type E surfaces described above are evident at scales from $0.1 \mathrm{~mm}$ to $1 \mathrm{~cm}$, and they typically cut across multiple crystals. Features at smaller scales of 0.02 to $0.5 \mathrm{~mm}$ that incise single crystals also exist and have been referred to as "microcorrosion" (Fig. 6A). For example, spötl et al. (2008) demonstrated microscopic evidence for microcorrosion (their Fig. 3D) in Stalagmite SPA121 from Spannagel Cave in the Austrian Alps, and Driese et al. (2012) observed similar features in a stalagmite from Raccoon Mountain Cave in eastern Tennessee, USA. Luetscher et al. (2011) reported micro-corrosion from Milchbach Cave in the Swiss Alps on a stalagmite surface at which dissolution had followed crystallographic planes (their Fig. 5C). These micro-corrosion surfaces are small-scale Type E surfaces, and in fact crystallographically controlled micro-corrosion can be seen on surfaces that, at larger scale, meet the criteria for Type $\mathrm{E}$ surfaces discussed above (Figs. 6B and 6C).

\section{Process}

The truncation of layers at Type E surfaces suggests that the surfaces result from some form of erosion. Removal of material within (rather than on) stalagmites and development of cavities analogous to microscopic caves demonstrates that this erosion is chemical rather than physical, and is the result of dissolution of spelean carbonate. This requires that the water falling on the stalagmite be undersaturated with respect to the stalagmite's calcite or aragonite. This conclusion, combined with the evidence from larger detrital material for gushing cave waters, suggests that Type E surfaces form in times of rainfall greater than normal. For example, undersaturation could occur either when water passes through the rock above the cave quickly enough to not reach chemical equilibrium with the $\mathrm{CaCO}_{3}$ of the overlying limestone, or when that water enters the cave and reaches the stalagmite so quickly that it has no time to degas and go from undersaturation to supersaturation (Fig. 5). The common deposition of calcite over Type E surfaces, even in stalagmites dominantly of aragonite (as in Figs. $3 \mathrm{C}, 3 \mathrm{E}, 4 \mathrm{~B}$, and $4 \mathrm{C}$ ), further suggests the association of Type E surfaces with wetter conditions (Murray, 1954; Pobeguin, 1965; Siegel, 1965; Siegel \& Dort, 1966; Thrailkill, 1971; Cabrol \& Coudray, 1982).

Stalagmites can also be truncated by breakage, most commonly by seismic disturbance (e.g., Forti, 2001; Sebela, 2008; Fairchild \& Baker, 2012). However, in contrast to Type E surfaces, such breakage commonly does not follow layers (e.g., Photo 3 of Cadorin et al., 2001), and even if it followed layers it would not be localized at the crest of a stalagmite (cf. Fig. 1). Furthermore, breakage cannot remove material from 
Normal deposition
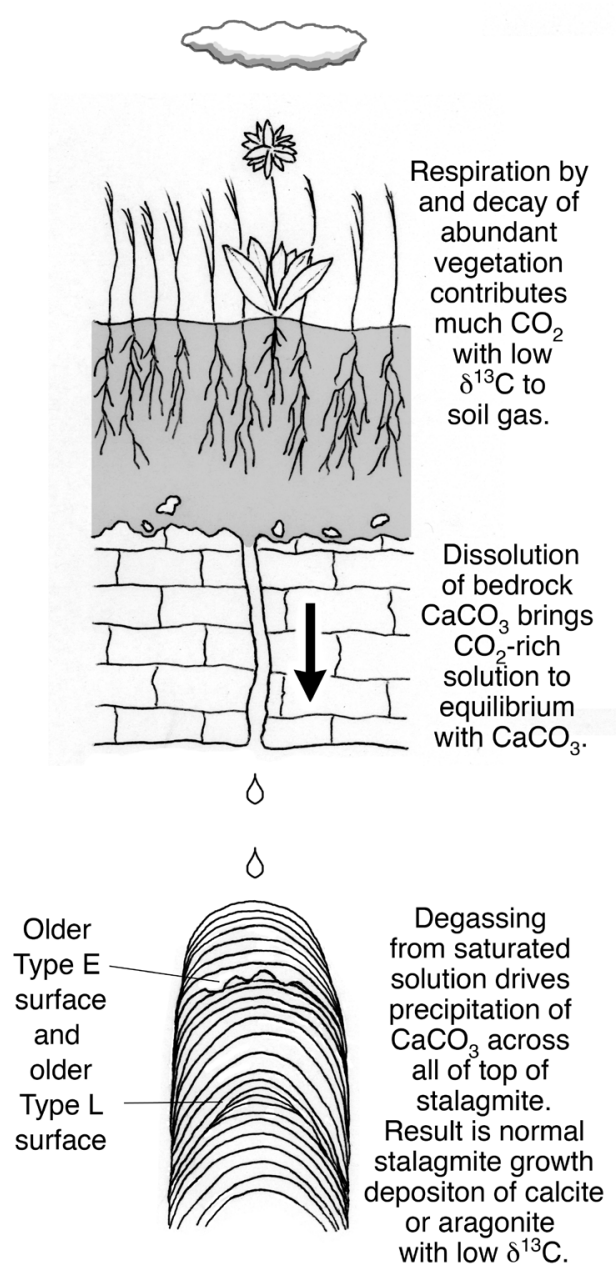

Type E
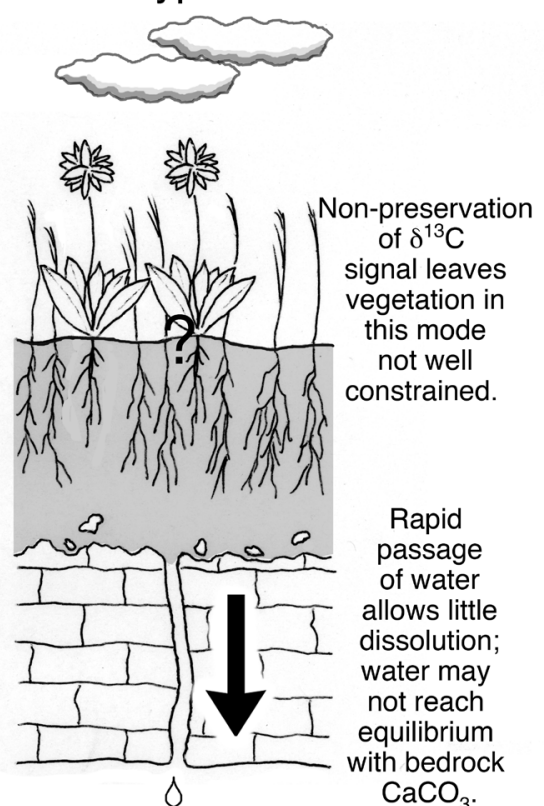

$\diamond$

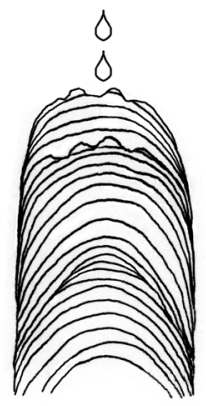

Rapid passage of water may not allow time for degassing to bring solution

to equilibrium with $\mathrm{CaCO}_{3}$ Result is corrosion of stalagmite and a Type E
Type L

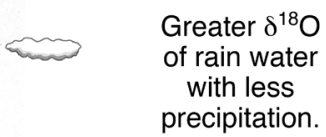

with less

precipitation.

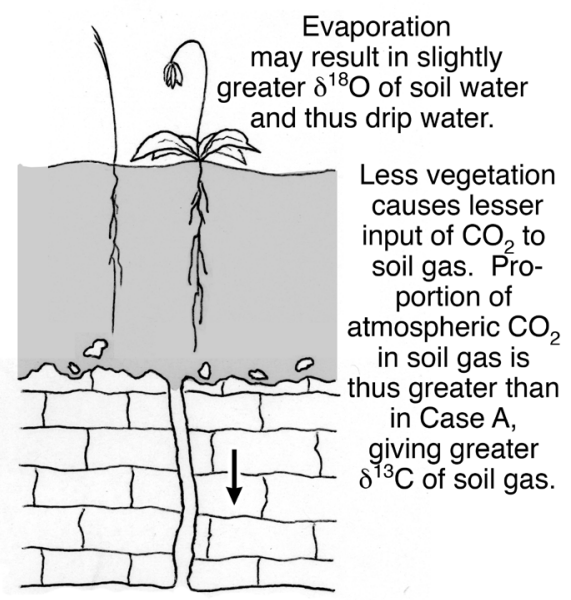

Little or no drip water. surface.

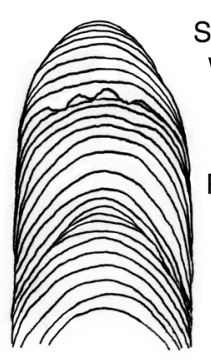

Small quantity of water charged with little $\mathrm{CO}_{2}$ produces little $\mathrm{CaCO}_{3}$ Result is layers of high- $\delta^{13} \mathrm{C}$ aragonite that do not cover entire stalagmite and a Type L surface.

Fig. 5. Sketches illustrating conditions conducive to development of Type E and Type L layer-bounding surfaces. Inferences regarding hydrologic conditions are supported by stable isotope data from Stalagmite ESP03 (Railsback et al., 2011), Stalagmite DP1 (Sletten et al., 2013), and the Wudu stalagmite (Xiao, 2003). The figure is adapted from Railsback et al. (2011).

within the stalagmite to yield the cave-like features at Type E surfaces described above (Figs. 1 and 4). The criteria that define Type E surfaces thus should preclude confusion with surfaces resulting from breakage.

\section{Duration of hiatus}

The apparent removal of $\mathrm{CaCO}_{3}$ at Type $\mathrm{E}$ surfaces suggests that any such surface represents a hiatus in the stalagmite's record of time. This relationship has been confirmed in Stalagmite ESP03 from Cova da Arcoia in northwestern Spain, where one Type E surface represents a hiatus of about 1000 years in a 9600-year record, and several others represent hiatuses of multiple centuries (Fig. 6 of Railsback et al., 2011). A Type E surface in Stalagmite BZBT1 from Belize likewise may represent a hiatus of 200 years in a record of at most 2000 years (Akers, 2011). On the other hand, the Type E surfaces in Stalagmite DP1 from northeastern Namibia represent such small hiatuses that they are insignificant in the construction of a chronology (Sletten et al., 2013), and the same is true of Type E surfaces in the Wudu stalagmite from north-central China studied by Xiao (2003). Where Type E surfaces represent a hiatus of significant duration, they can introduce abrupt changes in proxy records, as discussed further below.
Small or insignificant hiatuses may especially be characteristic of Type E surfaces with little vertical expression. For example, the chronology of Spötl et al. (2008) provided little evidence of a significant hiatus at their reported micro-corrosion surface, and similarly Luetscher et al. (2011) reported a surface of micro-corrosion but their chronology did not show a hiatus in that time interval. On the other hand, Driese et al. (2012) inferred hiatuses of at least centuries at the micro-scale corrosion surfaces in their Holocene stalagmite.

\section{TYPE L SURFACES}

\section{Petrography and process}

Type L layer-bounding surfaces are surfaces below which layers have lesser lateral extent upward and/ or become thinner upward (Figs. 1, 7, and 8). They thus represent lessened deposition, and hence the "L". The lesser lateral extent of layers below Type $\mathrm{L}$ surfaces means that stalagmites are commonly narrower beneath such surfaces (e.g., Figs. 8A and 8D). Layers beneath Type L surfaces are commonly aragonite rather than calcite (e.g., Figs. 7A and 7B). Stable isotope ratios, and especially $\delta^{13} \mathrm{C}$, commonly increase beneath Type L surfaces, as in Stalagmite 

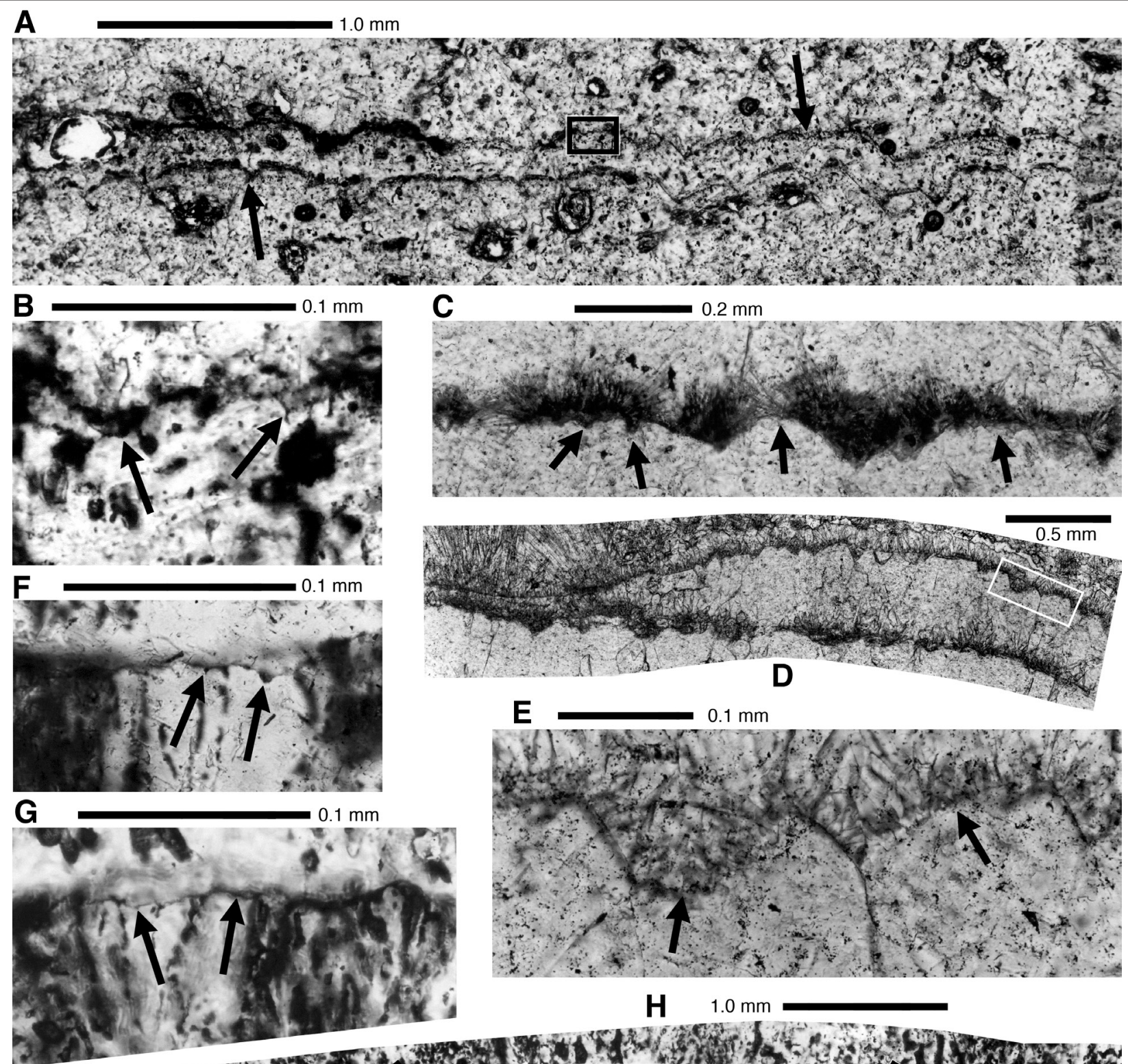

\section{H}

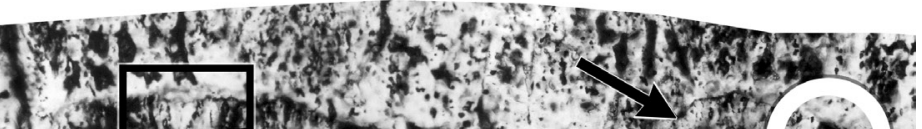

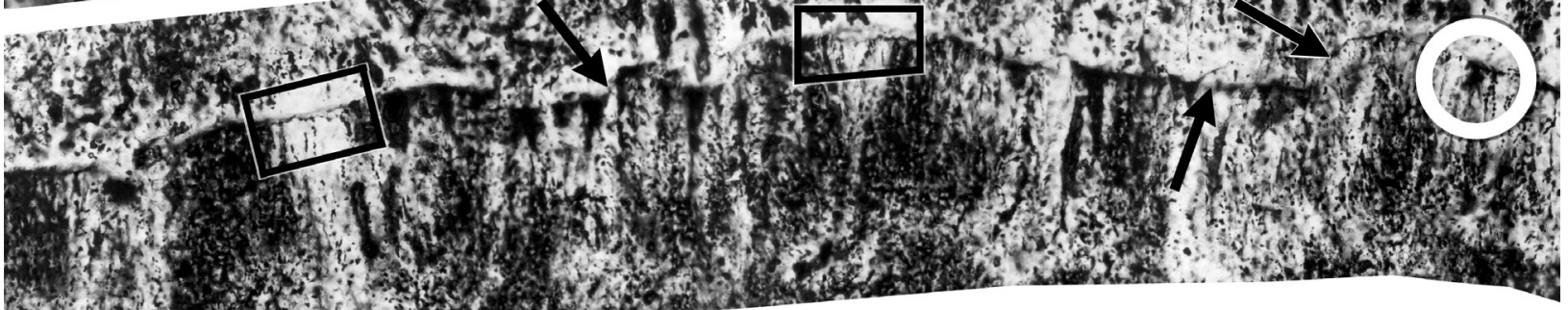

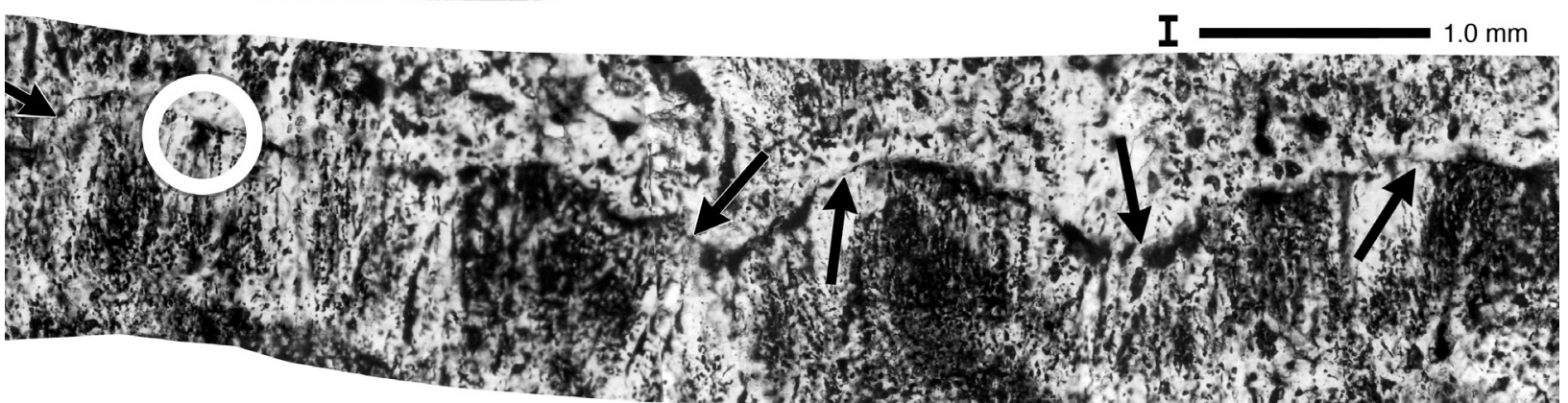

Fig. 6. Type $E$ layer-bounding surfaces $(A, C, D$, and $H$ to $I)$ at which there is microscopic expression of corrosion (B, C, E, F, and $G)$. A. Two Type E surfaces (arrows) in Stalagmite EG in southern Mexico. Note coating of detrital material on most of the two surfaces. Rectangle encloses non-coated area shown in Part B. B. Enlargement of non-coated area in rectangle in Part A. Corroded surface of calcite (arrows) in area enclosed by rectangle in Part A. C. Dissolutional pits (arrows) in calcite. D. Type E surface with underlying layer increasingly truncated to left. White rectangle at right encloses area shown in Part E. E. Corroded terminations of calcite crystals in area enclosed in white rectangle in Part D. Examples shown in Parts C, D, and E are from Stalagmite GG from New Mexico in the southwestern United States. F and G. Corroded surface of calcite (arrows) in rectangles along Type $\mathrm{E}$ surface that is shown in Parts $\mathrm{H}$ and I. H and I. Type E surface (arrows) in Stalagmite MA3 from Madagascar. $\mathrm{H}$ is left half and $\mathrm{I}$ is right half of one view along one Type $\mathrm{E}$ surface; white circle highlights on reference point visible in both images. Quadrilaterals in H outline areas shown in Parts F and G. Note extreme topography developed to right in Part I. 


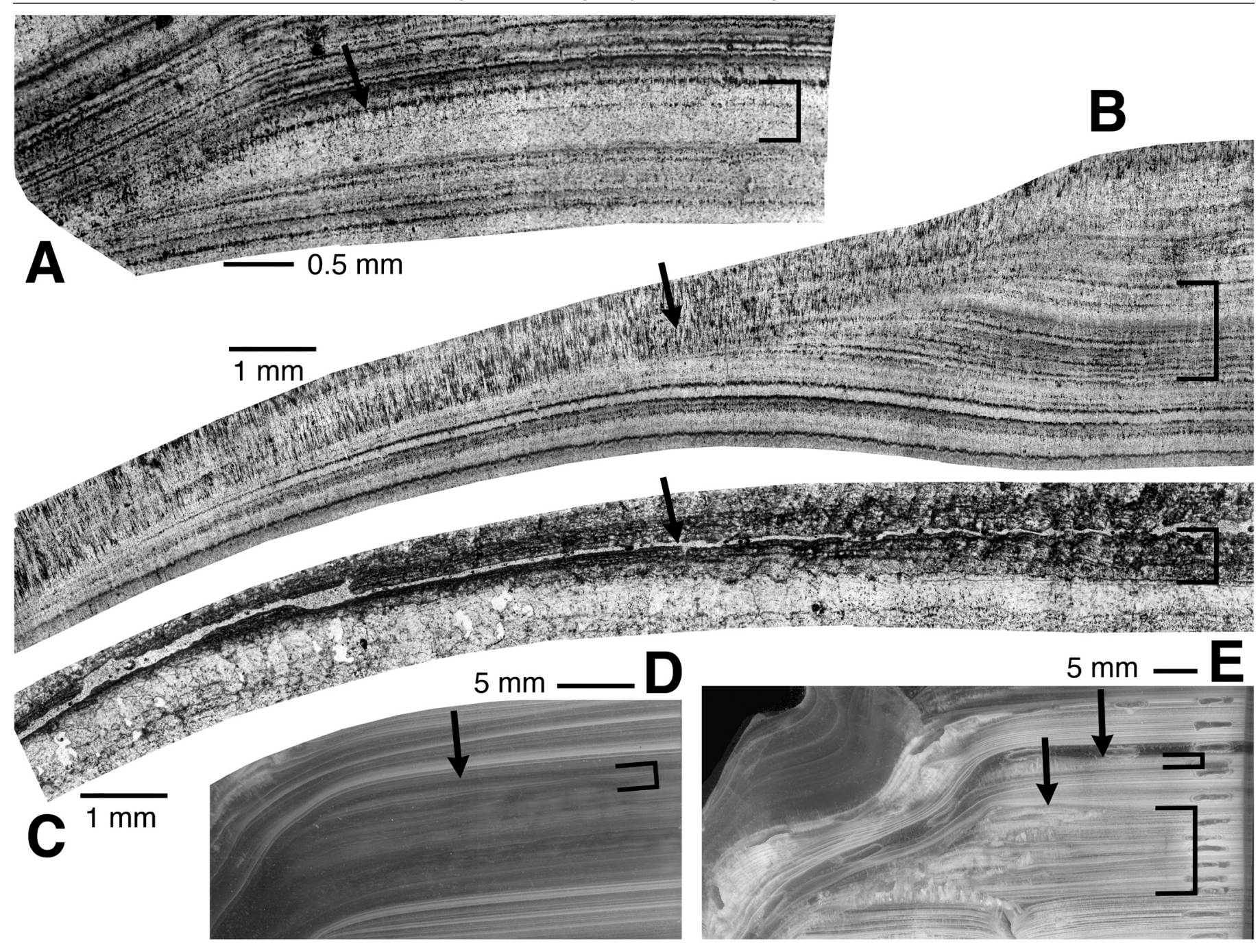

Fig. 7. Small-scale examples of Type $L$ layer-bounding surfaces. A. Type $L$ surface below which an interval of clear layers thins to flank of stalagmite at left. B. Type L surface below which layers in bracketed interval at right thin to flank of stalagmite at left. A and B are from Stalagmite ESP03 from northwestern Spain. C. Type L surface in Stalagmite MC1 from Belize. Note extent to which layers in bracketed interval at right thin toward flank of stalagmite at left. Dark color is result of fine-grained non-carbonate material that may be dust accumulated as aerosol during dry period, as proposed by Webster et al. (2007). D and E. Type E surfaces (arrows) at which bracketed intervals at right thin toward flank of stalagmite at left in Wudu stalagmite from north-central China.

ESP03 from northwestern Spain (Railsback et al., 2011), in the Wudu stalagmite from north-central China (Xiao, 2003), and in Stalagmite BZBT1 from Belize (Akers, 2011). In contrast to Type E surfaces, fine-grained detrital sediment is not notably associated with Type L surfaces, and coarser siltto-sand-sized detrital grains are not associated with Type L surfaces at all.

The lesser lateral extent of layers below Type L surfaces suggests that they form during diminishing flow of water onto the stalagmite (Dreybrodt, 1999), so that little drip water reaches the stalagmite and, in caves where evaporation occurs, even less water reaches its flanks. Greater values of $\delta^{13} \mathrm{C}$ associated with Type L surfaces likewise suggest drier conditions, in that less extensive soil respiration and/or the presence of $\mathrm{C} 4$ vegetation can lead to greater $\delta^{13} \mathrm{C}$ of spelean $\mathrm{CaCO}_{3}$. The frequency of aragonite beneath Type L surfaces further suggests that such surfaces form in drier conditions (Murray, 1954; Pobeguin, 1965; Siegel, 1965; Siegel \& Dort, 1966; Thrailkill, 1971; Cabrol \& Coudray, 1982). Finally, the scarcity of silt-to-sand-sized detrital grains near Type L surfaces is at least compatible with, if not suggestive of, development of those surfaces in drier conditions because less intense dripwater flow would lessen water-borne transport of coarser detrital grains. On the other hand, Dredge et al. (2013) have proposed that aerosols might allow deposition of some very fine-grained material during cessation of drips, and both Bertaux et al. (2002) and Webster et al. (2007) inferred deposition of dust on surfaces at which precipitation of $\mathrm{CaCO}_{3}$ ceased (Fig. 7c).

One might argue that Type $L$ surfaces could form not only as the result of drier climate but also as the result of hydrogeological changes, such as blockage of dripwater pathways or lateral drift of drip points. However, these changes would have to be reversible, because the Type L layer-bounding surfaces considered here both overlie previous deposits and, more critically, underlie later deposits that require resumption of their drips. In addition, lateral drift of a drip point should be evident in migration of the crest of a stalagmite's layers below the Type L surface. Minor migration of the crest is evident at some Type L surfaces, as in Figure 8a, but the migration is not sufficient to indicate drift of the drip off the stalagmite. 


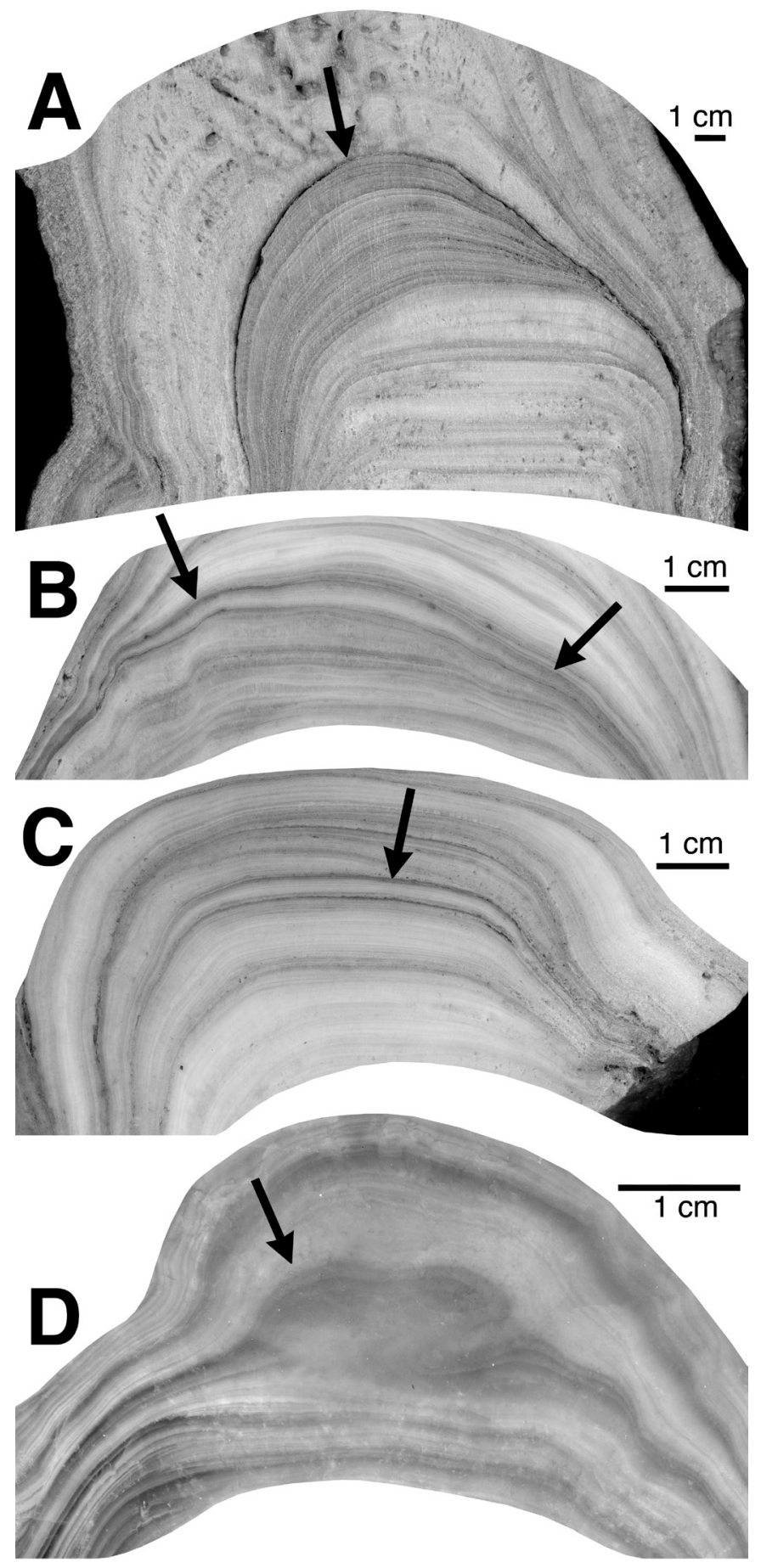

Fig. 8. Large-scale examples of Type L layer-bounding surfaces. A. Type $L$ surface in Stalagmite ANJ94-5 from Madagascar. Note lesser lateral extent of layers in 1 to $2 \mathrm{~cm}$ below surface. $B$ and $C$. Type $L$ surfaces in Stalagmite WG1 from Namibia. Note lesser lateral extent of white intervals below surfaces. $D$. Type $L$ surface in Stalagmite BRU 11 from Argentina. Note lesser lateral extent of dark interval just below surface.

\section{Duration of hiatus}

A Type L surface may, but does not necessarily, represent a hiatus in deposition. In the Wudu stalagmite from north-central China, Type L surfaces represent hiatuses of as much as 3000 years (Xiao, 2003), and the Type L surface in Stalagmite ANJ945 from Madagascar represents a hiatus of about 900 years. Type L surfaces in Stalagmite DP1 from northeastern Namibia do not represent demonstrable hiatuses but are in a zone of extremely slow growth (Sletten et al., 2013). On the other hand, Type L surfaces in Stalagmite ESP03 from northwestern Spain do not represent hiatuses recognizable at the scale of the dating available for that stalagmite (Railsback et al., 2011). An even more striking example comes from a stalagmite from Obir Cave in Austria, where Fairchild et al. (2010) in their Figure 4b documented a Type L layer-bounding surface that they inferred to result from lessened drip rate and that represented a hiatus of just one year.

\section{SIGNIFICANCE OF LAYER-BOUNDING SURFACES TO PALEOCLIMATE STUDIES}

\section{Interpretation of changing climate}

The association of Type E and Type L surfaces with wetter and drier conditions, respectively, has obvious implications for the development of histories of climate change. Most paleoclimate research has depended on oxygen and carbon stable isotope data for indications of climate change, but the interplay of atmospheric temperature, amount effects, and cave temperature make the interpretation of $\delta^{18} \mathrm{O}$ data complex if not uncertain (McDermott, 2004), and uncertainties in interpreting $\delta^{13} \mathrm{C}$ data lead many authors to not report their $\mathrm{C}$ isotope data at all. Recognition of Type $\mathrm{E}$ and Type L surfaces allows inferences of wetter and drier conditions that can support or discredit hypothesized interpretations of a set of stable isotope data, and thus it can improve the ultimate interpretation of those data.

Petrographic recognition of layer-bounding surfaces can additionally inform climate histories from stalagmites in which recrystallization has made isotope data suspect. For example, where chronologies can be based on non-carbonate material, as by radiocarbon dating of organic matter (Akers, 2011) or OSL dating of detrital material (Chirienco et al., 2010), recognition of layer-bounding surfaces allows development of a paleoclimate history not reliant on a stalagmite's carbonate geochemistry.

\section{Chronologies and interpretation of time-series paleoclimate data}

One important component in the application of a stalagmite to paleoclimatology is construction of an age model or chronology, where these terms refer to a graphic and/or mathematical relationship assigning an age to every positional increment along the stalagmite's growth axis. This effort commonly results in a published plot of age and position in which the chronology is represented by a line, series of line segments, or curve that relates position to inferred age (e.g., Fig. 4 of Spötl et al., 2008; Fig. 3 of Holzkämper et al., 2009; Fig. 2 of Dominguez-Villar et al., 2009; Fig. 5 of Brook et al., 2010; Fig. 6 of Railsback et al., 2011; Fig. 3 of Luetscher et al., 2011; Fig. 9 of this paper). The construction of such age models or chronologies is critical to the development of an environmental history (Telford et al., 2004; Blaauw, 2010; Scholz et al., 2012).

Recognition of layer-bounding surfaces can profoundly affect the construction of the age model or chronology from a stalagmite. That is because such surfaces indicate the existence of a hiatus (where 

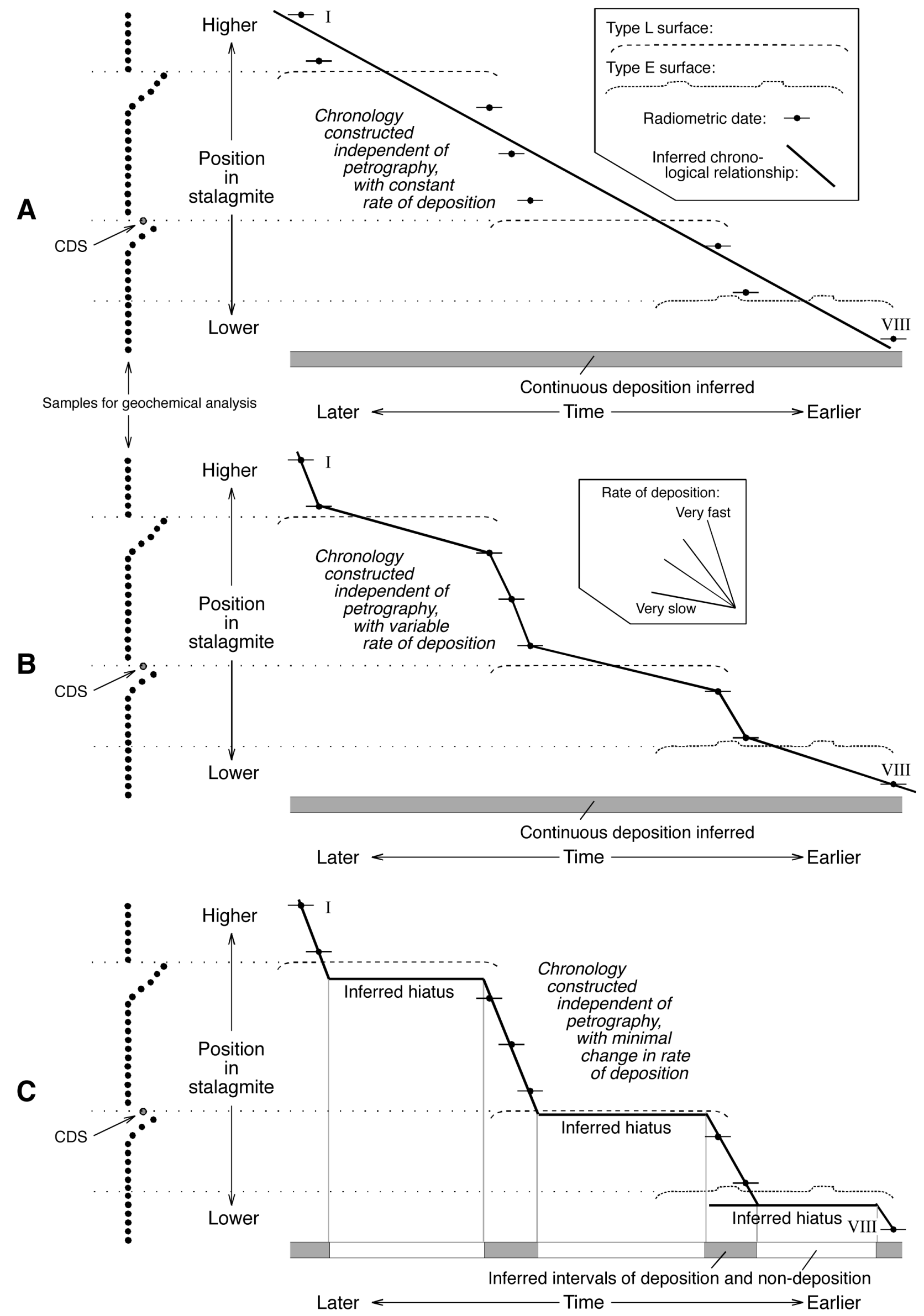

Fig. 9. Five possible chronologies, or age models, for the hypothetical stalagmite shown in Figure 10. For each, horizontal axis is time during deposition, and vertical axis is position in stalagmite. Series of filled circles to the left of each plot indicate positions of geochemical samples; measured results are greater from left to right. "CDS" indicates a "chronologically disjunct sample" of spelean carbonate from both below and above a layer-bounding surface, and thus from both before and after a hiatus. Figure 11 shows plots of the geochemical data generated assuming the different chronologies shown here. Roman numbers I and VIII indicate two of eight radiometric dates whose positions are shown in Figure 10. A, B, and $\mathrm{C}$ are examples of poorly constructed chronologies, as discussed in text. (Fig. 9 continued on following page.) 


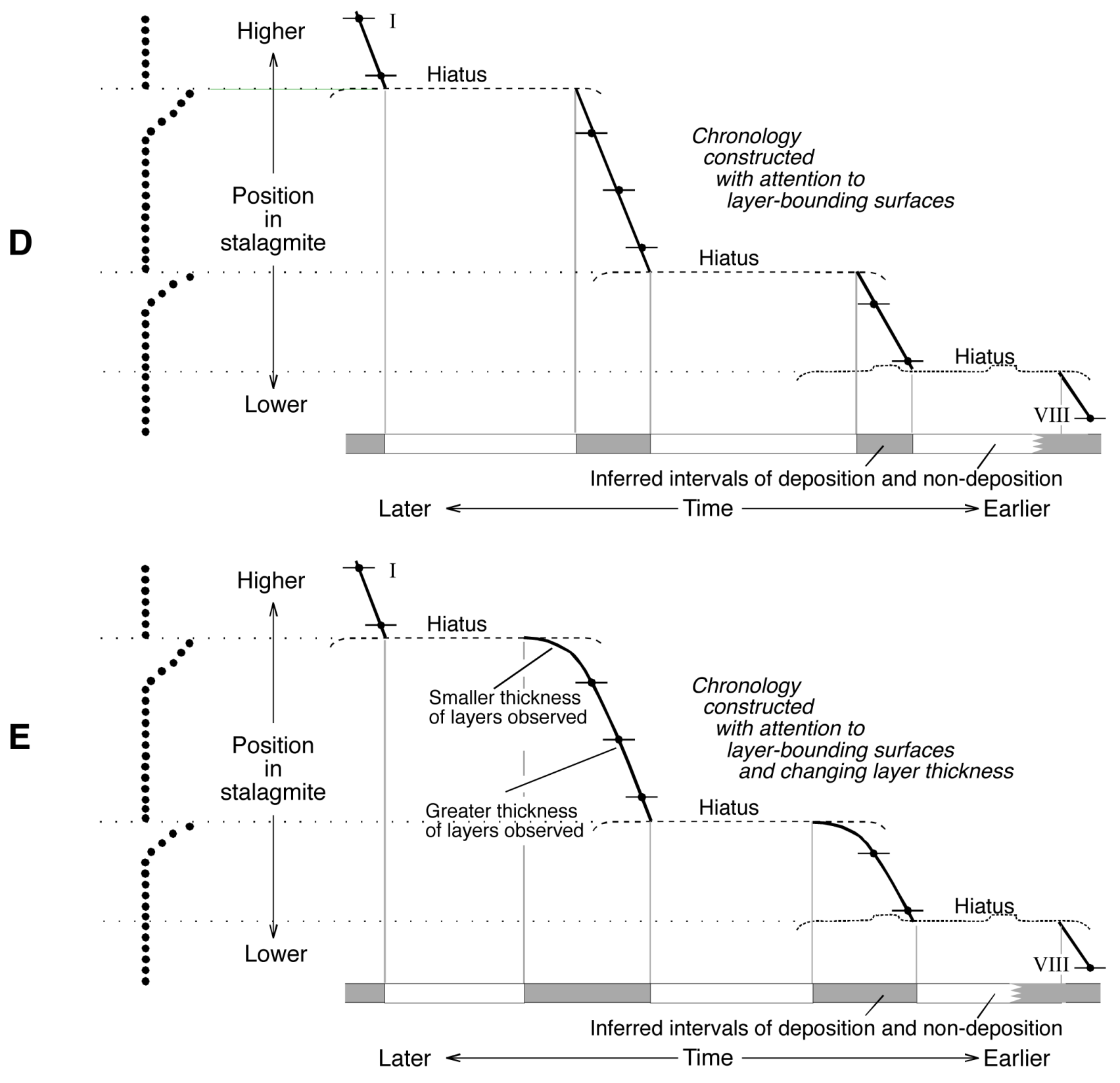

Fig. 9 continued.

a hiatus is otherwise not recognized) or the correct placement of a hiatus (where a hiatus is suspected but its position is otherwise unknown). To illustrate this, Figure 9 shows five different chronologies constructed from one hypothetical set of radiometric dates from one hypothetical stalagmite, which is shown in Figure 10. Figure 11 correspondingly shows five time series generated from one hypothetical set of isotopic data plotted according to the five chronologies in Figure 9. The dates come from a hypothetical stalagmite in which there are two Type L surfaces and one Type E surface (Fig. 10).

Of the five chronologies, Chronologies A, B, and C are constructed with no awareness of the layer-bounding surfaces. Chronology A assumes uninterrupted deposition and a constant rate of deposition for the entire stalagmite, and thus it consists of one straight line. In modern research, Chronology A would likely be questioned because it assigns ages outside the range of uncertainty for many of the dates. However, some papers published recently each include at least a single case of such nonconformity to radiometric dates and their uncertainties. Examples include the date $6 \mathrm{~cm}$ from the top of Stalagmite W5 studied by Holzkämper et al. (2009) and the date $18.5 \mathrm{~mm}$ from the top of Stalagmite ESP03 by Railsback et al. (2011). Application of Chronology A to a set of stable isotope or other data from the stalagmite in Figure 10 would yield the time-series of data in Figure 11A. Inattention to layer-bounding surfaces would lead to some data from diachronous samples taken across the unrecognized layer-bounding surfaces; these chronologically disjunct samples ("CDS" in Figs. 9 and 11) falsely smooth abrupt transitions in the data. In addition, some transitions in the time series would seem exceptionally abrupt because the large times that they span would not be recognized without recognition of the layer-bounding surfaces.

Chronology B assumes uninterrupted deposition but changing rates of deposition, and it thus consists of a series of joined line segments. It resembles many chronologies published in recent years, including 


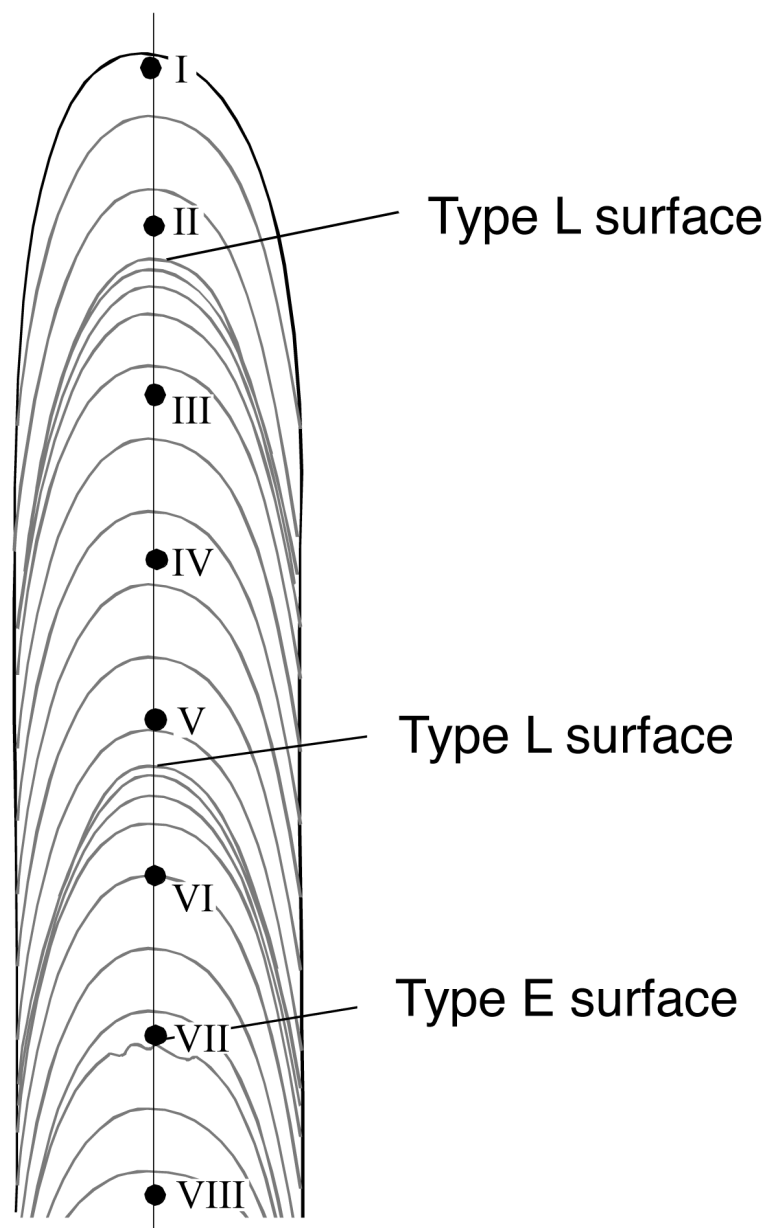

Fig. 10. Sketch of a hypothetical stalagmite considered further in Figures 9 and 11. Filled circles are positions of samples for radiometric dates.

those for Stalagmite SPA121 of Spötl et al. (2008) and Stalagmites MB3 and MB5 of Luetscher et al. (2011), and for large intervals of the chronologies for Stalagmite LV5 of Dominguez-Villar et al. (2009) and Stalagmite W5 of Holzkämper et al. (2009). It would, however, indicate incorrect ages for the intervals between Dates II and III, V and VI, and VII and VIII, because it does not take into account the three hiatuses at the three layer-bounding surfaces. As with Chronology A, stable isotope and other data taken using Chronology B could include diachronous samples across the unrecognized layer-bounding surfaces, and some transitions in the time series would be exceptionally abrupt and thus suggest improbably rapid ecological transitions. Chronology B would also incorrectly suggest an uneven spacing of samples in the time domain (Fig. 11B). Diligent researchers would take additional samples in time intervals that were seemingly sparsely sampled, which would only help to conceal the displacement of data in time and would likely lead to recovery of more diachronous samples across the unrecognized layer-bounding surfaces.

Chronology C assumes discontinuous deposition, with breaks in deposition where radiometric dates suggest either very slow growth or hiatuses. Those breaks must fall between two noticeably different ages, but the radiometric data provide no other criteria to dictate the exact positions of those breaks. As a result, the specific example shown as Chronology $\mathrm{C}$ in Figures 9 and 11, with its specific positioning of hiatuses, is just one of a large number of chronologies that could be generated using the same principles but with differing arbitrary positioning of the inferred hiatuses. Chronology $\mathrm{C}$ resembles many chronologies published in recent years, including that of Brook et al. (2010) where a hiatus inferred at $46 \mathrm{~cm}$ could seemingly be anywhere between 42 and $48 \mathrm{~cm}$ of a sequence $55 \mathrm{~cm}$ long. It also resembles the chronology derived from a hypothetical set of data by Scholz \& Hoffman (2011), where radiometric data only constrain a hiatus to be anywhere between 380 and $400 \mathrm{~mm}$ from the top of a stalagmite $450 \mathrm{~mm}$ long. Differing choices for the positions of hiatuses can lead to very different times assigned to geochemical samples (Fig. 11C). In the real-world chronology by Brook et al. (2010), differing placement of the hiatus inferred at 46 $\mathrm{cm}$ would change the age of some samples by 9,000 to 10,000 years, and in the hypothetical example by Scholz \& Hoffman (2011) differing arbitrary placement of the hiatus would change the age of some samples by about 8,000 years.

Chronology D assumes discontinuous deposition, with breaks in deposition at layer-bounding surfaces. Its breaks in deposition thus coincide with the best available evidence for timing of the hiatus. In this respect, it is superior to Chronology C, where positions of the inferred hiatuses are not supported by petrographic evidence, and far superior to Chronologies $\mathrm{A}$ and $\mathrm{B}$, which have no hiatuses at all. Chronology D assumes constant rates of deposition within a single continuous growth interval, but rates that may differ from one interval to the next. It thus consists of a series of isolated line segments. Chronology D is an analog of the chronology of Stalagmite ESP03 from Cova da Arcoia in northwestern Spain by Railsback et al. (2011) and of Stalagmite CBD-2 from southwestern Mexico by Bernal et al. (2011), who included photomicrographs of what we would categorize as Type E surfaces.

Chronology E, like Chronology D, assumes discontinuous deposition with breaks in deposition at layer-bounding surfaces, and thus like Chronology D it has hiatuses at positions supported by petrographic evidence. However, Chronology $\mathrm{E}$ assumes rates of deposition that vary as suggested by changing layer thickness. Thus, where layers thin beneath Type L surfaces and thereby suggest a lesser rate of deposition or growth rate, rate of deposition in the chronology diminishes. The exact extent of this change in rate cannot be determined precisely without an infinite number of radiometric dates spaced infinitely closely. However, Chronology E presents a more realistic and more probable relationship between position and age than does Chronology $\mathrm{D}$, which is in turn much more realistic than Chronologies $\mathrm{A}, \mathrm{B}$, and $\mathrm{C}$.

\section{CONCLUSIONS}

Two kinds of layer-bounding surfaces in stalagmites, Type E and Type L, can be recognized according to explicitly-defined criteria (Table 1; Fig. 1). Recognition of these surfaces provides paleoclimatological information that can complement or even substitute 


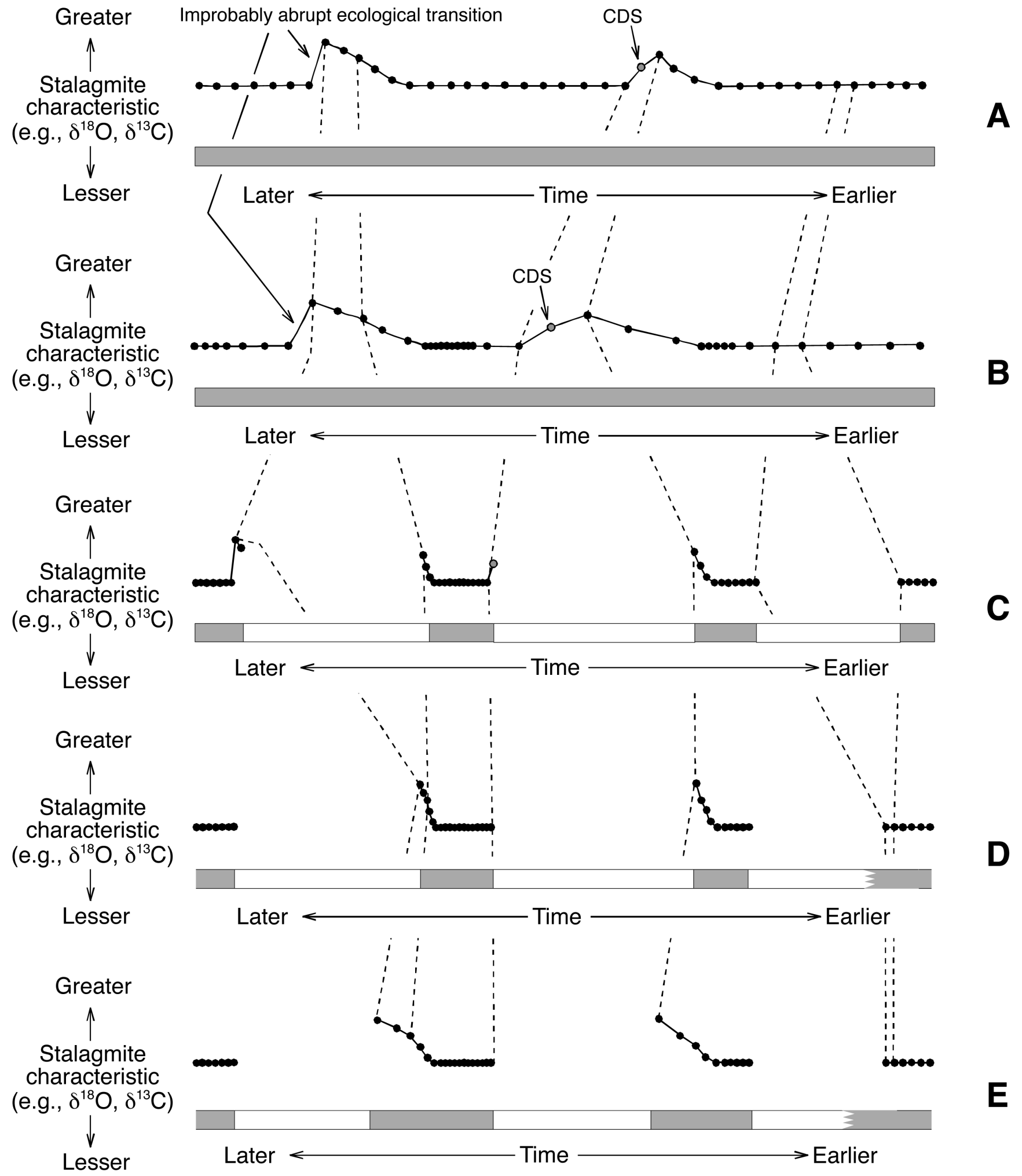

Fig. 11. Proxy records of past climate constructing using data from samples in stalagmite shown in Figure 10, using the chronologies in Figure 9. Parts A, B, C, D, and E correspond to Chronologies A, B, C, D, and E of Figure 9. Dashed lines join like samples and thus illustrate the extent to which ages assigned to proxy data depend on chronology used. "CDS" indicates a "chronologically disjunct sample" of spelean carbonate from both below and above a layer-bounding surface, and thus from both before and after a hiatus.

for geochemical proxies. Recognition of these surfaces also greatly improves development of chronologies or age models, in that petrographically-constrained incorporation and placement of hiatuses yields more accurate relationships between position and age. Future paleoclimatological research using stalagmites would therefore be enhanced by petrographic, as well as geochemical, analysis of stalagmites. Further research may also recognize other kinds of layerbounding surfaces and/or other origins of hiatuses as this area of speleothem research develops.

\section{ACKNOWLEDGEMENTS}

The stalagmites shown here were collected by Dr. George A. Brook of the University of Georgia (USA), 
Dr. Juan Ramón Vidal Romani of the University of A Coruña (Spain), Dr. Ming Tan of the Chinese Academy of Sciences, Dr. Eugene Marais of the National Museum of Namibia, Dr. James W. Webster of the United States Environmental Protection Agency, Dr. Honglin Xiao of Elon College (USA), and PDA and GAH. The thin sections used were prepared using funds from grants from the U.S. National Oceanographic and Atmospheric Administration and National Science Foundation to Dr. George A. Brook and L Bruce Railsback, and from grants from the Spanish Ministry of Science and Technology to Dr. Juna Ramón Vidal Romani. Professor Ian Fairchild of the University of Birmingham and an anonymous reviewer are thanked for their suggestions with regard to the literature.

\section{REFERENCES}

Akers P.D., 2011 - Climate \& Maya cultural change: Detecting connections using Belizean stalagmites. M.S. Thesis, University of Georgia, Athens, Georgia, U.S.A.

Baker A., Smart P. L., Edwards R.L. \& Richards D.A., 1993 - Annual growth banding in a cave stalagmite. Nature, 364: 518-520. http://dx.doi.org/10.1038/364518a0

Bernal J.P., Lachniet M., McCulloch M., Mortimer G., Morales P. \& Cienfuegos E., 2011 - A speleothem record of Holocene climate variability from southwestern Mexico. Quaternary Research, 75: 104-113.

http://dx.doi.org/10.1016/j.yqres.2010.09.002

Bertaux J., Sondag F., Santos R., Soubiès F., Causse C., Plagnes V., Le Cornec F. \& Seidel A., 2002 - Paleoclimatic record of speleothems in a tropical region: Study of laminated sequences from a Holocene stalagmite in Central-West Brazil. Quaternary International, 89: 3-16. http://dx.doi.org/10.1016/S1040-6182(01)00077-5

Blaauw M., 2010 - Methods and code for 'classical' age-modelling of radiocarbon sequences. Quaternary Geochronology, 5: 512-518. http://dx.doi.org/10.1016/j.quageo.2010.01.002

Brook G.A., Rafter M.A., Railsback L.B., Sheen S.-W. \& Lundberg J., 1999 - A high-resolution proxy record of rainfall and ENSO since $A D 1550$ from layering in stalagmites from Anjohibe Cave, Madagascar. The Holocene, 9: 695-705.

http://dx.doi.org/10.1191/095968399677907790

Brook G.A., Ellwood B.B., Railsback L.B. \& Cowart J.B., 2006 - A 164 ka record of environmental change in the American Southwest from a Carlsbad Cavern speleothem. Palaeogeography, Palaeoclimatology, Palaeoecology, 237: 483-507.

Brook G.A., Scott L., Railsback L.B. \& Goddard E.A., 2010 - A $35 \mathrm{ka}$ pollen and isotope record of environmental change along the southern margin of the Kalahari from a stalagmite and animal dung deposits in Wonderwerk Cave, South Africa. Journal of Arid Environments, 74: 870-884. http://dx.doi.org/10.1016/j.jaridenv.2009.11.006

Cabrol P. \& Coudray J., 1982 - Climatic fluctuations influence the genesis and diagenesis of carbonate speleothems in southwestern France. National Speleological Society Bulletin, 44: 112-117.

Cadorin J.F., Jongmans D., Plumier A., Camelbeeck T., Delaby S. \& Quinif Y., 2001 - Modelling of speleothems failure in the Hotton cave (Belgium). Is the failure earthquake induced? Netherlands Journal of Geosciences / Geologie en Mijnbouw, 80: 315-321.

Chirienco M.I., Panno S.V., Lundstrom C.C., Hackley K.C. \& Hong W., 2010 - Interpretations of speleogenesis and paleoclimate from speleothems in Donnehue's Cave, Indiana. Geological Society of America Abstracts with Programs, 42 (5): 226.
Dominguez-Villar D., Fairchild I.J., Baker A., Wang X., Edwards R.L. \& Cheng H., 2009 - Oxygen isotope precipitation anomaly in the North Atlantic region during the 8.2 ka event. Geology, 37: 1095-1098. http://dx.doi.org/10.1130/G30393A.1

Dredge J., Fairchild I.J., Harrison R.M., FernándezCortès A., Sánchez-Moral S., Jurado J., Gunn J., Smith A., Spötl C., Mattey D., Wynn P.M. \& Grassineau N., 2013 - Cave aerosols: Distribution and contribution to speleothem geochemistry. Quaternary Science Reviews, 63: 23-41. http://dx.doi.org/10.1016/j.quascirev.2012.11.016

Dreybrodt W., 1999 - Chemical kinetics, speleothem growth and climate. Boreas 28: 347-356. http://dx.doi.org/10.1111/j.1502-3885.1999.tb00224.x

Driese S., Li Z.-H., Cheng H., Stinchcomb G.E., Kocis J.J., Horn S.P. \& Boehm M.S., 2012 - Speleothem micromorphology improves interpretations of floodplain paleoclimate records and enhances interpretations of the timing and structure of the mid-Holocene warm period. Geological Society of America Abstracts with Programs, 44 (7): 303.

Drysdale R.N., Spötl C., Hellstrom J.C. \& Richards D.A., 2012 - New advances in the dating of speleothems - An introduction. Quaternary Geochronology, 14: 1-4. http://dx.doi.org/10.1016/j.quageo.2012.11.008

Fairchild I.J., Spötl C., Frisia S., Borsato A., Susini J., Wynn P.M., Cauzid J. \& EIMF, 2010 - Petrology and geochemistry of annually laminated stalagmites from an Alpine cave (Obir, Austria): seasonal cave physiology. In: Pedley H.M. \& Rogerson, M. (Eds.) Tufas and Speleothems: Unravelling the Microbial and Physical Controls. Geological Society, London, Special Publication, 336: 295-321.

Fairchild I.J. \& Baker A., 2012 - Speleothem Science. Chichester, Wiley-Blackwell, 432 p.

Forti P., 2001 - Seismotectonic and paleoseismic studies from speleothems; the state of the art. Geologica Belgica, 4: 175-185.

Frisia S., Borsato A., Fairchild I.J., McDermott F. \& Selmo E.M., 2002 - Aragonite-calcite relationships in speleothems (Grotte de Clamouse, France): Environment, fabrics, and carbonate geochemistry. Journal of Sedimentary Research, 72: 687-699.

http://dx.doi.org/10.1306/020702720687

Holzkämper S., Holmgren K., Lee-Thorp J., Talma A., Mangini A. \& Partridge T., 2009 - Late Pleistocene stalagmite growth in Wolkberg Cave, South Africa. Earth and Planetary Science Letters, 282: 212-221.

http://dx.doi.org/10.1016/j.epsl.2009.03.016

Lachniet M.S., 2009 - Climatic and environmental controls on speleothem oxygen-isotope values. Quaternary Science Reviews, 28: 412-432.

http://dx.doi.org/10.1016/j.quascirev.2008.10.021

Luetscher M., Hoffman D.L., Frisia S. \& Spötl C., 2011 Holocene glacier history from alpine speleothems, Milchbach cave, Switzerland. Earth and Planetary Science Letters, 302: 95-106. http://dx.doi.org/10.1016/j.eps1.2010.11.042

Mariethoz G., Kelly B.F.J. \& Baker A. 2012 Quantifying the value of laminated stalagmites for paleoclimate reconstructions. Geophysical Research Letters, 39: L05407.

http://dx.doi.org/10.1029/2012GL050986

McDermott F., 2004 - Palaeo-climate reconstruction from stable isotope variations in speleothems: a review. Quaternary Science Reviews, 23: 901-918.

http://dx.doi.org/10.1016/j.quascirev.2003.06.021

Murray J.W., 1954 - The deposition of calcite and aragonite in caves. Journal of Geology, 62: 481-492. http://dx.doi.org/10.1086/626192 
Pobeguin Th., 1965 - Surles concretions calcaires observées dans la Grotte de Moulis (Ariège). Société Géologique de la France, Compte Rendus, 241: 1791-1793.

Polyak V.J. \& Asmerom Y., 2001 - Late Holocene climate and cultural changes in the southwestern United States. Science, 294: 148-151.

http://dx.doi.org/10.1126/science.1062771

Railsback L. B., Brook G. A., Chen J., Kalin R. \& Fleischer C. J., 1994 - Environmental controls on the petrology of a Late Holocene speleothem from Botswana with annual layers of aragonite and calcite. Journal of Sedimentary Research, A64: 147-155.

Railsback L.B., Liang F., Vidal Romaní J.-R., Grandal d'Anglade A., Vaqueiro Rodríguez M., Santos Fidalgo L., Fernández Mosquera D., Cheng H. \& Edwards R.L., 2011 - Petrographic and isotopic evidence for Holocene long-term climate change and shorter-term environmental shifts from a stalagmite from the Serra do Courel of northwestern Spain, and implications for climatic history across Europe and the Mediterranean. Palaeogeography, Palaeoclimatology, Palaeoecology, 305: 172-184. http://dx.doi.org/10.1016/j.palaeo.2011.02.030

Scholz D. \& Hoffmann D.L, 2011 - StalAge - An algorithm designed for construction of speleothem age models. Quaternary Geochronology, 6: 369-382. http://dx.doi.org/10.1016/j.quageo.2011.02.002

Scholz D., Hoffmann D.L., Hellstrom J. \& Ramsey C.B., 2012 - A comparison of different methods for speleothem age modeling. Quaternary Geochronology, 14: 94-104. http://dx.doi.org/10.1016/j.quageo.2012.03.015

Sebela S., 2008 - Broken speleothems as indicators of tectonic movements. Acta Carsologica, 37: 51-62.

Shen C.C., Edwards R.L., Cheng H., Dorale J.A., Thomas R.B., Moran S.B., Weinstein S.E. \& Edmonds H.N., 2002 - Uranium and thorium isotopic and concentration measurements by magnetic sector inductively coupled plasma mass spectrometry. Chemical Geology, 185: 165-178.

http://dx.doi.org/10.1016/S0009-2541(01)00404-1

Siegel F.R., 1965 - Aspects of calcium carbonate deposition in Great Onyx Cave, Kentucky. Sedimentology, 4: 285-299. http://dx.doi.org/10.1111/j.1365-3091.1965.tb01552.x

Siegel F.R. \& Dort W. Jr., 1966 - Calcite-aragonite speleothems from a hand-dug cave in northeast Kansas. International Journal of Speleology, 2: 165-169. http://dx.doi.org/10.5038/1827-806X.2.1.15
Sletten H.R., Railsback L.B., Liang F., Brook G.A., Marais E., Hardt B.F., Cheng H. \& Edwards R.L., 2013 - A petrographic and geochemical record of climate change over the last 4600 years from a northern Namibia stalagmite, with evidence of abruptly wetter climate at the beginning of southern Africa's Iron Age. Palaeogeography, Palaeoclimatology, Palaeoecology, 376: 149-162. http://dx.doi.org/10.1016/j.palaeo.2013.02.030

Spötl C., Scholz D. \& Mangini A., 2008 - A terrestrial U/Thdated stable isotope record of the Penultimate Interglacial. Earth and Planetary Science Letters, 276: 283-292. http://dx.doi.org/10.1016/j.eps1.2008.09.029

Tan M., Baker A., Genty D., Smith C., Esper J. \& Cai B., 2006 - Applications of stalagmite laminae to paleoclimate reconstructions: Comparison with dendrochronology/ climatology. Quaternary Science Reviews, 25: 2103-2117. http://dx.doi.org/10.1016/j.quascirev.2006.01.034

Telford R.J., Heegaard E. \& Birks H.J.B., 2004 - All agedepth models are wrong: but how badly? Quaternary Science Reviews, 23: 1-5. http://dx.doi.org/10.1016/j.quascirev.2003.11.003

Thrailkill J., 1971 - Carbonate deposition in Carlsbad Caverns. Journal of Geology, 79: 683-695. http://dx.doi.org/10.1086/627698

Turgeon S. \& Lundberg J., 2001 - Chronology of discontinuities and petrology of speleothems as paleoclimatic indicators of the Klamath Mountains, southwest Oregon, USA. Carbonates and Evaporites, 16: 153-167. http://dx.doi.org/10.1007/BF03175833

Vail P.R., Mitchum R.M. Jr., Todd R.G., Widmier J.M., Thompson S. III, Sangree J.B., Bubb J.N. \& Hatlelid W.G., 1977 - Seismic stratigraphy and global changes of sea level. In: Payton C.E. (Ed.), Seismic Stratigraphy: Applications to Hydrocarbon Exploration. American Association of Petroleum Geologists Memoir, 26, Tulsa: 49-212.

Webster J.W., Brook G.A., Railsback L.B., Cheng H., Edwards R.L., Alexander C. \& Reeder P.R., 2007 Stalagmite evidence from Belize indicating significant droughts at the time of Preclassic Abandonment, the Maya Hiatus, and the Classic Maya Collapse. Palaeogeography, Palaeoclimatology, Palaeoecology, 250: 1-17. http://dx.doi.org/10.1016/j.palaeo.2007.02.022

Xiao H., 2003 - Climate and land use records for China from cave stalagmites and satellite images. Ph.D. Dissertation, University of Georgia, Athens, Georgia, U.S.A. 